\title{
PROBIOTIC CANDIDATE PROTEOLYTIC Bacillus sp. COLLECTED FROM MANGROVE OF MARGASARI, LAMPUNG
}

\author{
Sumardi ${ }^{1}$, Komang Rima ${ }^{1}$, Salman Farisi ${ }^{1}$, and Endang Linirin Widiastuti ${ }^{1,2, *}$ \\ ${ }^{1}$ Biology Department, Faculty of Mathematics and Natural Sciences, University of Lampung \\ Jl. Prof. Dr. Ir. Sumantri Brojonegoro, No. 1, Bandar Lampung, Lampung 35141, Indonesia \\ ${ }^{2}$ Coastal and Marine Research Center, University of Lampung \\ Jl. Sumantri Brojonegoro No. 1. Bandar Lampung, Lampung 35141, Indonesia
}

Received: 10 June 2020, Revised: 25 March 2021, Accepted: 5 April 2021

PROBIOTIC CANDIDATE PROTEOLYTIC Bacillus sp. COLLECTED FROM MANGROVE OF MARGASARI, LAMPUNG. Intensive shrimp culture has encountered many problems, such as declining water quality through disease caused by pathogenic microbes, which affected mortality. This study aimed to determine any potential probiotic from Bacillus sp. collected from mangrove in East Lampung, which could be used to improve the cultured shrimps' proteolytic and probiotic activity. This is a descriptive research with sampling and data collection of bacteria from many samples of mangrove. Result shows 128 isolates Bacillus from which then it has arrived at five potential probiotic Bacillus sp. The study five Bacillus sp. has been isolated with potential properties for probiotic (KPP212, IP121, UJ131, UJ132, SB141). Each isolate has characteristics with proteolytic property, growth in a wide range of $\mathrm{pH} 4-10$ and osmotic stress $(0-6 \%$ $\mathrm{NaCl}$ ), non-pathogenic, ability for glucose fermentation, non-motile, and has negative catalase activity. The five potential Bacillus sp. can be used as probiotics for shrimp farming.

Keywords: Characterisation, Bacillus sp., mangrove, probiotic

KANDIDAT PROBIOTIK PADA Bacillus sp. PROTEOLITIK DIKOLEKSI DARI HUTAN MANGROVE DI MARGASARI, LAMPUNG. Budidaya udang dengan cara intensif telah menyebabkan banyak masalah seperti penurunan kualitas air yang mengakibatkan munculnya mikroba patogen, sebingga mempengarubi kematian. Tujuan dari penelitian ini adalah untuk, menemukan Bacillus sp. yang diisolasi dari beberapa sampel di mangrove dan mengkarakterisasi mikroba terisolasi tersebut untuk penggunaan probiotik. Studi ini merupakan penelitian deskriptif dan koleksi data bakteri dari berbagai jenis sampel mangrove. Dari penelitian ditemukan lima Bacillus sp. yang terisolasi dan memiliki sifat potensial untuk, probiotik, yaitu KPP212, IP121, UJ131, UJ132, dan SB141, dengan masing-masing isolat memiliki karakteristik bersifat proteolitik, pertumbuban dalam rentang pH yang luas (4-10) dan taban pada tekanan osmotik. (0-6\% $\mathrm{NaCl})$, tidak, patogen, kemampuan untuk. fermentasi glukosa, tidak motil, serta tidak memiliki aktivitas katalase. Kelima bakteri Bacillus sp. tersebut dapat digunakan untuk probiotik, pada budidaya udang.

Kata kunci: Karakterisasi, Bacillus sp., mangrove, probiotik

*Corresponding author: elwidi@yahoo.com 


\section{INTRODUCTION}

Mangrove of Margasari Village in the district of Labuhan Maringgai, East Lampung Regency is in $5^{\circ} 51^{\prime} 84^{\prime \prime}$ South Latitude-105 $64^{\prime} 84^{\prime \prime}$ East Longitude covers about 700 hectares which is $6.65 \%$ of the total mangrove in Lampung Province. Mangrove has functions ecologically and economically, such as protecting coastal abrasion, brackish water quality control, habitat for many organisms, medicines, and paper pulp. The presence of waste influences mangrove's ecological activities, decomposition by microorganisms, mineral uptaking by plants, and other biological activities to keep the equilibrium (Kementerian Kehutanan, 2014; Kariada \& Andin, 2014). Furthermore, it is necessary to rehabilitate mangrove for further conservation of coastal areas.

Many researchers in various places have also isolated the bacteria potential from mangrove. The study of Deivanai, Bindusara, Prabhakaran, and Bhore (2014) isolated Pantoea ananatis (1MSE1) and Bacillus amyloliquefaciens (3MPE1) bacteria from mangrove, which is interacted positively with rice seedlings, provides significant increase in root and shoot length, fresh weight, and chlorophyll content. The study of Castro et al. (2018) proved that Enterobacter sp. MCR1.48 strain from mangrove endophyte effectively promotes the Acacia polyphylla growth and fitness. The bacteria can be used in the seedling production of the tree. Another researcher, Maulani, Rasmi, and Zulkifli (2019), has successfully isolated eighteen endophytic bacteria from mangrove Rhizophora mucronata from Gili Sulat, East Lombok. The 18 isolates of endophytic consist of 15 isolates: Grampositive bacteria and 3 isolates were Gramnegative bacteria. The endophytic bacteria isolate that had antibiotic activity was B. cereus, $P$. aeruginosa, $S$. aureus, and E. coli. On the other hand, the potential fungi from mangrove were also discovered. Hamzah, Lee, Hidayat, Terhem, Hanum, and Mohamed (2018) in Malaysia isolated endophytic fungi from mangrove Rhirophora mucronata. The study found several fungi, i.e. Alternaria, Fusarium, Nigrospora, Pestalotiopsis, Phoma, and Xylaria. After their culture assay for their antagonism activities with the phytopathogenic fungus, Fusarium solani reached $45-66 \%$. Of the six isolates, only Fusarium lateritium and Xylaria sp. showed antibacterial activities against the pathogenic bacteria, Bacillus subtilis, Escherichia coli, Pseudomonas aeruginosa, and Staphylococcus aureus.

Mangrove plays an important role in the coastal waters, food web and habitat, supporting many different biotas, such as fish, crabs, shrimps, and molluscs (Scharler, 2011). Around the Margasari mangrove, there are shrimp farmings. The mangrove has many wastes, which is good nutrition for various bacterial growths. In nature, the bacteria can pass into the digestive tract of animals. Several types of bacteria found in the digestive tract of animals had an important role in improving food and fish's healthy utilisation (Sarastiti, Suminto, \& Sarjito, 2020). Bacillus sp. can be one of the bacteria that can increase the digestibility of fish or shrimp, and it has the potential as a probiotic (Anggriani, Iskandar, \& Ankiq, 2012). There was no information related to the isolation of Bacillus sp. from mangrove of Margasari, East Lampung, especially related to those used for probiotics.

The advantage of probiotic technology is that the process is natural and safe. Probiotics had a beneficial effect which includes interacting directly with commensal and pathogenic microorganisms. The probiotics were used for many functions, i.e. (1) to prevent and treat infections, (2) to improve the balance of microorganisms in the small intestine, (3) to produce extracellular enzymes, and (4) to produce beneficial compounds such as vitamins and short-chain fatty acids (Tensiska, 2008).

Isolation and selection of proteolytic bacteria have very good potential to be used as probiotics. The character of the bacteria is needed to increase feed efficiency. The study reported that shrimp and fish feed contained $55.51-67.68 \%$ protein (Handayani, 2011). 
Other studies have also shown some other microorganisms as probiotic candidates, and they were Bacillus subtilis, Bacillus licheniformis, Pseudomonas putida, Bacillus bataviensis, and Caulobacter sp. (Rahmawan, Mohamad, Suminto, \& Herawati, 2014; Seprianto, Feliatra, \& Nugroho, 2017).

Shrimp cultures have been widely growing in Lampung Province, in which intensive shrimp culture deliberates some diseases related to its culture (Taukhid, Supriyadi, \& Koesharyani, 2008). To prevent or regulate the disease, therefore, the development of probiotic is necessary. Samosir, Suryanto, and Desrita (2017) established one by developing probiotic from the surrounding ecosystem. Many isolated bacteria with potential sources of probiotic can be collected from mangrove communities, such as from mangrove plant (its root and bark), fishes like milky fish, cuttlefish, mangrove shrimps, molluscs, crabs, and other fishes, as well as from the mud, water and other abiotic factors of the mangrove ecosystem (Pratiwi, Rahayu, \& Wahju, 2013; Seprianto, Feliatra, \& Nugroho, 2017; Muliani, Nurbaya, Arifudin, \& Muharijadi, 2017). Therefore, it is necessary to figure out any potential of the proteolytic Bacillus sp. as a local probiotic is collected from the mangrove of Margasari. It could then be applied to the aquaculture digestion, and disease problems, especially in shrimp and fish cultures encountered most in Lampung Province.

\section{MATERIAL AND METHOD}

\section{A. Sources of Isolated Bacteria}

The sample used to isolate bacteria was collected from mangrove communities in Margasari Village, Labuhan Maringgai, East Lampung Regency. Abiotic and biotic samples were collected from water, mud, fishes, shrimps, crabs, mollusc and cuttlefish found in the mangrove ecosystem, as well as the Rhirophora sp. bark and roots.

\section{B. Isolation of Bacillus sp.}

Isolation of Bacillus sp. was done from different sample mass, $10 \mathrm{~g}$ of mud, $1 \mathrm{~g}$ mangrove root and skin, $1 \mathrm{ml}$ of water, $1 \mathrm{ml}$ intestinal suspension of shrimp, crab, mollusc, and fish (Figure 1). Sample suspension then was made by adding $90 \mathrm{ml}$ physiological salt for mud and $9 \mathrm{ml}$ for water, mangrove root and bark,
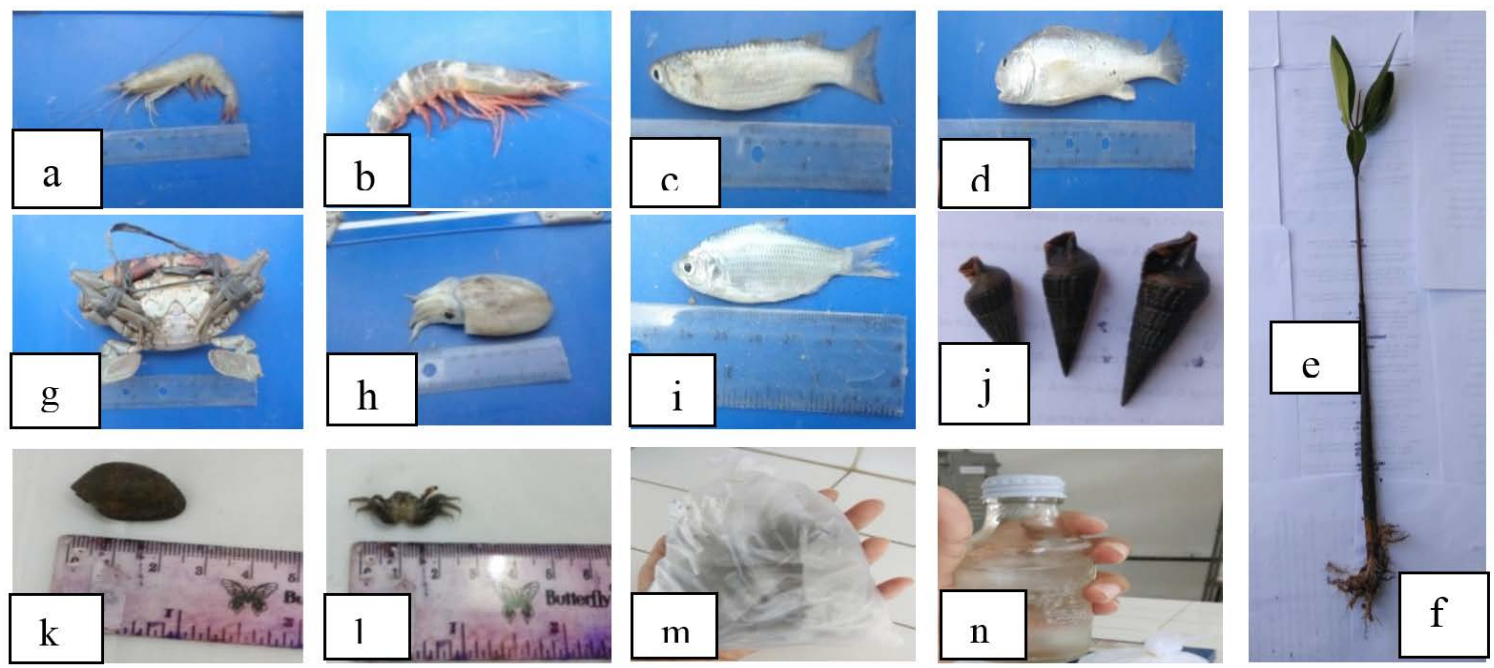

Figure 1. Collected biotic samples

Remarks: a. Penaeus merguiensis (udang jerbung), b. Litopenaeus vannamei (udang kucing) c. Mugil sp. (ikan belanak) d. Mallotus villosus (ikan kepala batu) e. Epidermis of Rhizopora sp.(kulit bakau), f. Root of Rhizopora sp. (akar bakau), g. Scylla serrata (kepiting bakau) h. Sepia latimanus (sotong), i. Tenualosa toli (ikan pirit), j. Telescopium telescopium (siput bakau) k. Nerita violacea (keong bulat), and l. Episesarma sp. (kepiting pemanjat pohon) and abiotic samples, $\mathrm{m}$. mud, and n. water 
shrimp, mollusc, crab and fish. All samples were homogenised by using a vortex mixer at $80^{\circ} \mathrm{C}$ for 15 minutes. Dilution was made for each sample in series of 10-1 and 10-2. one $\mathrm{ml}$ of each was diluted into sample suspension and it was spread into skim milk agar media modification of Sea Water Complete (SWC), followed by incubation for 24 hours at $37^{\circ} \mathrm{C}$ (Hamtini, 2014). The isolate then was purified by quadrant streak into the SWC agar media.

\section{Proteolytic Test}

Bacillus sp. isolate was picked using a sterile ose needle and inoculated into SWC media modified with skim milk. The culture then was incubated for 24 hours at $37^{\circ} \mathrm{C}$. The observation was made by determining the formed proteolytic index (Hamtini, 2014, Hapsari, Tjahjaningsih, Alamsjah, \& Pramono, 2016; Sumardi, Agustrina, Ekowati, \& Pasaribu, 2018).

\section{Osmotic/Salinity Stress Test}

Bacillus sp. isolate was picked using a sterile ose needle and inoculated into modified SWC media with $\mathrm{NaCl}$ concentration of $0 \%, 3 \%$, and $6 \%$. The culture then was incubated for 24 hours at $37^{\circ} \mathrm{C}$. The observation was made by determining the number of growing colonies (Subagiyo, Sebastian, Triyanto, \& Wilis, 2015).

\section{E. pH-stress Test}

Bacillus sp. isolate was picked using a sterile ose needle and inoculated into modified SWC

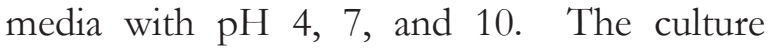
then was incubated for 24 hours at $37^{\circ} \mathrm{C}$. The observation was made by determining the measurement of growing colonies (Kepel, Widdhi, \& Fatimawali, 2020).

\section{F. Pathogenetic Test}

Bacillus sp. isolate was picked using a sterile ose needle and inoculated into blood modified SWC media. The culture then was incubated for 24 hours at room temperature (Hamtini, 2014). The observation was made by determining the hemolytic ability of isolate from the change of colours (Figure 2).

\section{G. Characteristic Test}

Characterisation of isolate bacteria, presumably Bacillus sp. was done in 2 steps, as follows:

a. Morphological characterisation of colony and cell. Colony characterisation was done by observing the colony formed while cell morphology was made on gram smear (Yulvizar, 2013).

b. Biochemical test

Biochemical test as characterisation of the colony was conducted in different tests, such as catalase, mortality and glucose fermentation.

b.1. Catalase test

Two drops of $\mathrm{H}_{2} \mathrm{O}_{2}$ was placed in the sterile glass. Then, one ose needle picked of isolate Bacillus sp. was mixed into $\mathrm{H}_{2} \mathrm{O}_{2}$ in object glass (Yulvizar, 2013).

b.2. Motility test

As much as 1 ose needle isolate Bacillus sp. was placed into SWC agar media SWC. The culture then was incubated for 24 hours at
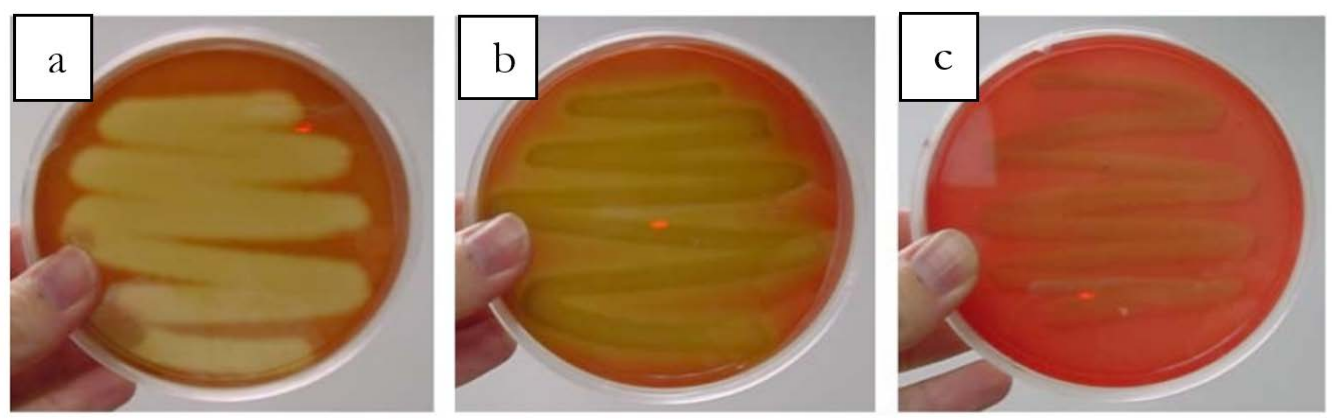

Figure 2. Hemolysis test in blood agar

Remarks: a. Beta hemolysis, b. Alpha hemolysis, c. Gamma hemolysis (Aryal, 2015) 
$37^{\circ} \mathrm{C}$ temperature (Samosir, Suryanto, \& Desrita, 2017).

\section{b.3. Glucose fermentation test}

As much as 1 ose needle isolate Bacillus sp. was inoculated into liquid SWC agar media and added 1\% sugar (glucose, lactose, mannitol, sucrose and mannose). The culture then was incubated for 24 hours at $37^{\circ} \mathrm{C}$ temperature (Samosir et al., 2017).

\section{III.RESULT AND DISCUSSION}

\section{A. Margasari Mangrove}

Margasari mangrove is very important for the coastal area of East Lampung. Most of the shrimp or fish cultures/ponds are found in the mangrove belt of East Lampung. It is known that mangrove can support many biotas, including fish, shrimps, molluscs (Figure 1). Margasari mangrove and other mangrove ecosystems provide food for many aquatic biotas and contribute to the biological cycle in coastal waters. With special structures of mangrove plants, such as Rhizophora mucronata, Avicennia marina., Sonneratia alba, and others, the mangrove's ground floor and swamp and water flow within the mangrove connecting provides shelter for many larvae of mangrove biota.

Spawning and nursery become the shelter of many biotas provided by mangrove, and it is affected by microbes activity as a decomposer. These microbes possibly believed to have beneficial uses such as probiotic, antibiotic, and bioactive products and else (Subagiyo, Muhammad, \& Wilis, 2017). The recent study also indicated that some mangrove shrubs, such as Acanthus ilicifolius contain antioxidant (Widiastuti, Arifianti, Khairani, Christianto, Ara, \& Maharani, 2019). Other studies showed that Bacillus sp. as probiotic bacteria had been found in Mangrove in Lampung (Sumardi, Farisi, Ekowati, \& Hairisah, 2019; Sumardi, Farisi, Ekowati, Arifiyanto, \& Rahmawati, 2020).

\section{B. Isolation of Bacillus sp.}

Five Bacillus sp. isolates were found from mangrove samples and predicted to be used potentially for probiotic. They were from climbing crab intestine, fish intestine, two isolat from shrimp and one from mollusc intestinethose five isolates. Bacillus sp. were collected after undergoing selection tests for potential candidate for probiotic and can be seen in Table 1.

Initially, the number of isolated and purified bacteria from collected samples were 128 , from which the highest isolated was from the mud (Table 1). The colour of mud was dark black, indicating it contained a high concentration of organic molecules (Suhendar, Esti, \& Asep, 2019). It could be used as an indicator that some bacterial colony could be found in the mud. Another study also found seven isolated bacteria collected from mangrove mud of Wonorejo, Rungkut, Surabaya (Pratiwi, Rahayu, \& Wahju, 2013). This diversity found in bacterial colonies was possible since the mangrove area was fully covered by plant debris that can be degraded and used by microorganisms as energy sources (Sinatryani, Moch, Sudarno, \& Kustiawan, 2014).

Fourteen bacterial isolation was found from squids which were the highest number of bacterial isolations found among others. Some studies also indicated that four different probiotic isolation was found from carpio fish intestine (Samosir, Suryanto, \& Desrita, 2017), while other studies were able to isolate 16 probiotic colonies from shrimp intestine (Febrianti, 2011). Isolation of this probiotic colony mostly was from the intestine/gut of the animal samples. Most of these variety microorganisms play an important role in the digestive system, like produced enzymes (Sarastiti, Suminto, \& Sarjito, 2020). In addition, the existing variety of microorganism was also able to compete with the growth of pathogenic bacteria and presumably increased animal immunity. With the normal digestive process, growth was affected, and the animal's development was the bacterial host (Samosir et al., 2017).

While those in plant parts, such as roots and skins of mangrove plants, 5 and 6 isolated 
Table 1. Number of Bacillus sp. from isolation and selection tests

\begin{tabular}{|c|c|c|c|c|c|c|c|}
\hline \multirow[b]{2}{*}{ Source } & \multirow[b]{2}{*}{$\begin{array}{l}\text { Type } \\
\text { of } \\
\text { Isolat }\end{array}$} & \multicolumn{2}{|c|}{ Protease Test } & \multicolumn{2}{|c|}{ Osmotic Stress Test } & \multicolumn{2}{|c|}{ Pathogen Test } \\
\hline & & $\begin{array}{c}\text { Non } \\
\text { Proteolytic }\end{array}$ & Proteolytic & $\begin{array}{l}\text { No growth } \\
\text { on pH and } \\
\text { salinity } \\
\text { stress tests }\end{array}$ & $\begin{array}{l}\text { Growth on } \\
\text { pH and } \\
\text { salinity } \\
\text { stress tests }\end{array}$ & Pathogen & $\begin{array}{c}\text { Non } \\
\text { Pathogen }\end{array}$ \\
\hline Water & 12 & 1 & 11 & 7 & 4 & 4 & 0 \\
\hline Mud & 22 & 4 & 18 & 16 & 2 & 2 & 0 \\
\hline Sepia latimanus & 14 & 9 & 5 & 4 & 1 & 1 & 0 \\
\hline Episesarma sp. & 11 & 5 & 6 & 3 & 3 & 2 & 1 \\
\hline Scylla serrata & 13 & 2 & 11 & 9 & 2 & 2 & 0 \\
\hline Tenualosa toli & 8 & 2 & 6 & 4 & 2 & 1 & 1 \\
\hline Penaeus merguiensis & 8 & 2 & 6 & 3 & 3 & 1 & 2 \\
\hline Telescopium telescopium & 7 & 1 & 6 & 2 & 4 & 3 & 1 \\
\hline Nerita violacea & 7 & 0 & 7 & 5 & 2 & 2 & 0 \\
\hline Litopenaeus vannamei & 5 & 2 & 3 & 2 & 1 & 1 & 0 \\
\hline Rhizopora sp. root & 5 & 2 & 3 & 2 & 1 & 1 & 0 \\
\hline Rhiropora sp. bark & 6 & 1 & 5 & 4 & 1 & 1 & 0 \\
\hline Mallotus villosus & 7 & 3 & 4 & 3 & 1 & 1 & 0 \\
\hline Mugilsp. & 3 & 0 & 3 & 3 & 0 & 0 & 0 \\
\hline Number & 128 & 34 & 94 & 67 & 27 & 22 & 5 \\
\hline
\end{tabular}

Table 2. Morphology of isolat Bacillus sp. for the probiotic candidate

\begin{tabular}{ccccccc}
\hline \multirow{2}{*}{ Isolat } & \multicolumn{3}{c}{ Colony } & \multicolumn{3}{c}{ Cell Morphology } \\
\cline { 2 - 6 } & Form & Edges & Elevation & Colors & Gram & Form \\
\hline KPP212 & Circular & Raised & Entire & White & + & Basil \\
IPI121 & Circular & Convex & Entire & White & + & Basil \\
UJ131 & Circular & Flat & Entire & White & + & Basil \\
UJ132 & Circular & Convex & Entire & White & + & Basil \\
SB141 & Irregular & Raised & Lobate & White & + & Basil \\
\hline
\end{tabular}

bacteria were found from each, the roots and skins of the mangrove plants were used since these parts of mangrove plants had to contact with mud and water, which presumably also contained bacteria which can be isolated, and had different characteristics with other bacterial colony found from animal samples. Yet, they had potential characteristic as probiotic candidates.

\section{Cell Morphology}

The morphology of isolate is correct bacteria, had a similarity, yet only the isolated colony's edge had a different shape (Table 2). In contrast, the cell morphology indicated the same shape and Gram stain, bacillus and positive Gram (Table 2 and Figure 3). Positive
Gram stain was indicated by the violet colour of the bacterial cell. The crystal violet was trapped in the thick cellular wall of bacteria with one layer membrane in which bacteria underwent dehydration and shrink after exposure to $96 \%$ alcohol (Samosir, Suryanto, \& Desrita, 2017).

\section{Proteolytic Test}

Many different tests were given to the isolated bacteria colony. This caused drastic selection among them. Before the selection was given, 128 isolated bacteria were found, then, with proteolytic selection, 94 isolates were collected. Further selection was made based on the ability to deal with salinity and $\mathrm{pH}$, the Bacillus sp. isolates were reduced to 27 isolates. 

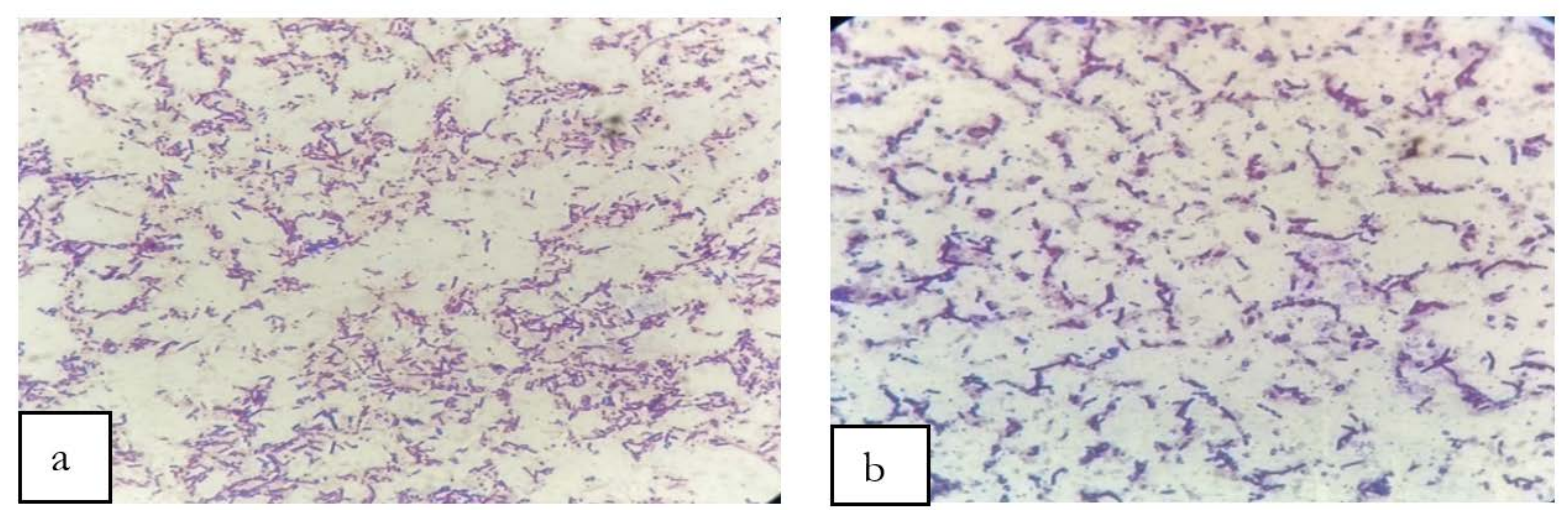

Figure 3. Cell morphology of isolat bacteria

Remarks: a. UJ132 and b. KPP212

Table 3. Proteolytic Index of isolat Bacillus sp.

\begin{tabular}{cccc}
\hline Isolat & $\begin{array}{c}\text { Area of Colony } \\
\left(\mathbf{c m}^{2}\right)\end{array}$ & $\begin{array}{c}\text { Area of clear zone } \\
\left(\mathbf{c m}^{2}\right)\end{array}$ & Proteolytic Index \\
\hline KPP212 & 0.50 & 1.22 & 2.44 \\
IP121 & 0.94 & 2.11 & 2.24 \\
UJ131 & 0.22 & 1.17 & 5.26 \\
UJ132 & 0.56 & 1.67 & 3.00 \\
SB141 & 0.72 & 1.94 & 2.69 \\
\hline
\end{tabular}

The final selection was made for their ability to be pathogenic to ensure that the bacterial colony caused no harm if they were given probiotics. Characteristics of Bacillus sp. could be seen in Table 3 .

The protein contained in shrimp feeds is approximately $30-40 \%$. Therefore, proteolytic test was necessarily performed. All the isolated probiotic candidates indicated their ability to degrade casein from media, indicated by clear zone as hydrolysis process surrounding the isolated colony (Figure 3). This ability was also indicated by those colonies of probiotic candidates obtained from other studies (Samosir et al., 2017). The proteolytic ability of Bacillus sp. occurred since the bacteria produced protease (Hamtini, 2014). Protease, as the extracellular enzyme of Bacillus sp. can break the peptide bond of protein into oligopeptida and amino acids (Ilmiah, Nisa, \& Budiasih, 2018).

A study on the potential of proteolytic bacteria from mangroves also has been observed by other researchers. Utomo et al.
(2019) succeeded in observing the protease enzyme-producing bacteria from the mangrove of Gunung Anyar, Surabaya. Two species of bacteria was obtained, namely Yersinia enterocolotica and Enterobacter agglomerans. The bacteria have been characterised as the proteolytic enzyme. Other researchers, Castro et al. (2014), isolated endophytic microorganisms from two mangrove species, Rhizophora mangle and Avicennia nitida. They found that mangrove microorganisms demonstrated a diverse range of enzymatic activities. The isolates produced enzymes of amylase, esterase, lipase, protease, and endoglucanase. In this study Bacillus sp. of proteolytic and non-pathogenic was observed as a potential probiotic.

All the collected isolate probiotic candidates showed different proteolytic index. The isolate bacteria with the highest proteolytic index was in code SB141, while the lowest was in code IP121. This different proteolytic index can be seen in each isolate bacteria's clear zone (Figure 4). 


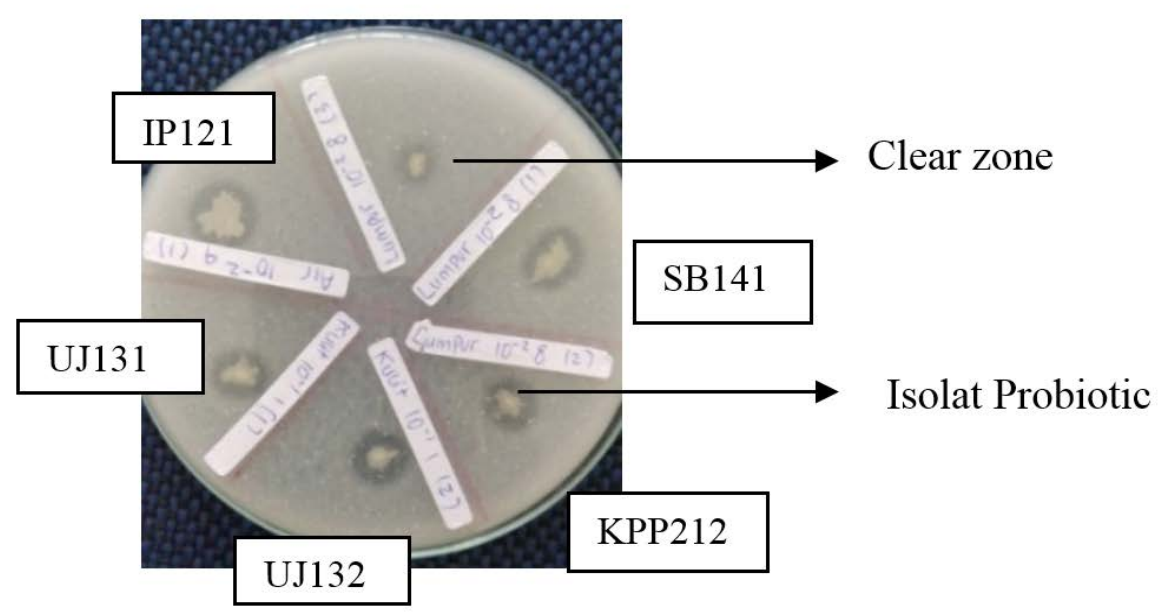

Figure 4. Illustration of the proteolytic index of Bacillus sp.

Remarks: Salinity and $\mathrm{pH}$ tests were conducted to elucidate selected isolate probiotic candidates' ability from different salinity and $\mathrm{pH}$ stresses of media. Isolate with codes of KPP212, IPI21, UJ131, UJ132 and SB141 survived and grew in salinity of $0 \%, 3 \%$, and $6 \%$ and with $\mathrm{pH}$ of 4,7 , and 10

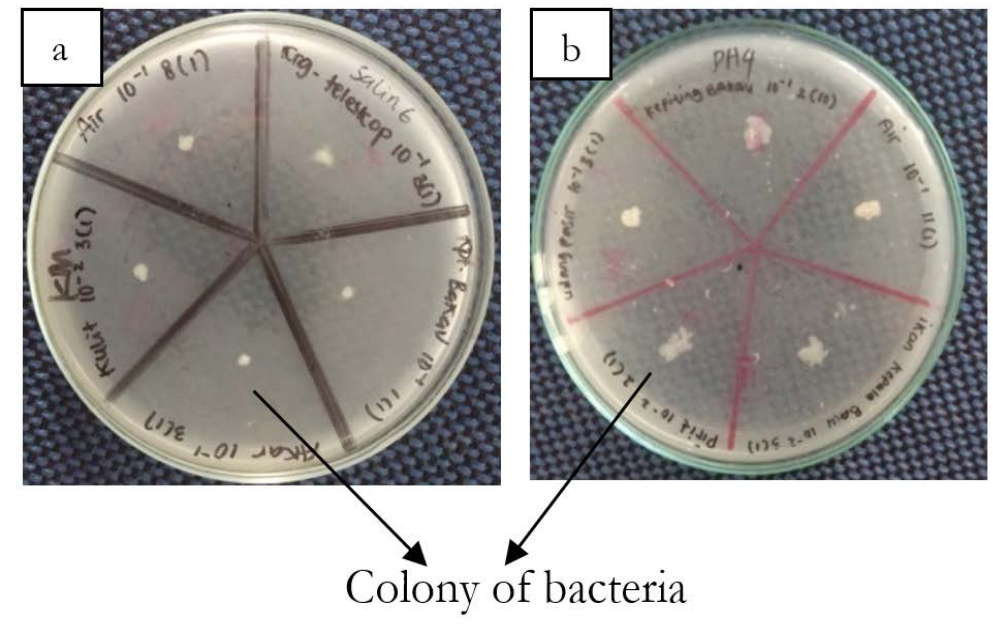

Figure 5. Colony of bacteria under saline 6\% (a) and $\mathrm{pH} 4$ (b)

Salinity and $\mathrm{pH}$ tests were conducted to elucidate selected isolate probiotic candidates' ability from different salinity and $\mathrm{pH}$ stresses of media. Isolate with codes of KPP212, IPI21, UJ131, UJ132, and SB141 survived and grew in salinity of $0 \%, 3 \%$, and $6 \%$ and with $\mathrm{pH}$ of 4 , 7 , and 10 .

\section{E. Bacteria Characterisation}

The five isolated bacteria produced protease and survived in a different range of $\mathrm{pH}$ (410) and different salinity (0-6\%) (Figure 5); meanwhile, their hemolysis activity was in gamma hemolysis or non-pathogenic activity. All the isolated ones also indicated non-motile, and only isolated with code UJ132 had positive catalase activity from biochemical tests. In contrast, in the sugar fermentation test, all isolated ones had positive results in all different types of sugar used for the test.

The ideal of probiotic is survival in many different stress conditions; therefore survival test was conducted. Isolates of KPP212, IPI21, UJ131, UJ132 and SB141 indicated that they 
can survive and grew very well in $\mathrm{pH}$ and salinity stress (Figure 4).

This ability to survive was similar to those found by another study (Triyanto, Isnansetyo, Prijambada, Widada, \& Tarmiawati, 2009) was isolated from the mangrove's mud. This bacteria colony's survival from different stress of $\mathrm{pH}$ and salinity presumably showed that this colony was used to environmental stress, unstable condition, which is very common in estuary ecosystem (Hutabarat, 2000).

Pathogenicorvirulentisolateswasdetermined by the degree of clear zone media produced by the isolates. All the isolates probiotic candidates had $\gamma$ (Gamma) hemolysis characteristic (Table 4). Blood agar as differentiates media was used to determine bacteria's ability to lyse red blood cells (RBCs) (Hamtini, 2014). The ability of bacteria to lyse RBCs was done by extra-cellular protein produce called haemolysin (Khusnan, Dwi, \& Agus, 2018). Pathogenetic in RBCs was defined into three levels, alpha hemolysis, betha hemolysis and gamma hemolysis. Alpha hemolysis occurred when RBCs and hemoglobin were partly lyzed, betha hemolysis occurred when all RBCs and hemoglobin were lyzed, causing the surrounding media to clear. Gamma hemolysis occurred when there was no lysis for both RBCs and hemoglobin, causing no colour change in media (Hamtini, 2014).

In the sugar fermentation test, all of the isolates colony indicated positive fermentation test for sugars such as lactose, mannose, mannitol, glucose and sucrose (Table 4), indicated by the formation of yellow colour media. The change in media colour occurred since fermentation caused acidity of the media in which, by using phenol red as an indicator, it turned to yellow. Acids released in media was produced from the breaking down of sugar by bacteria. In the motility test, all isolates indicated negative results, shown by the bacteria colony's undispersed growth in their media (Damayanti, Oom, \& Effendi, 2018).

A catalase test was done to determine the ability of the isolates colony to produce catalase enzyme. A positive result was shown from the UJ132 isolate, while KPP212, IP121, UJ131, and SB141 isolates indicated negative results (Table 4). A positive result was indicated by an oxygen bulb from mixing of $\mathrm{H}_{2} \mathrm{O}_{2}$ with isolate bacteria, indicating that catalase enzyme was produced by bacteria and used to break hydrogen peroxide in water and oxygen. Hydrogen peroxide was a compound that interferes with intracellular enzyme activity (Yulvizar, 2013).

Table 4. Bacteria isolated characterisation

\begin{tabular}{|c|c|c|c|c|c|c|c|c|c|c|c|c|c|c|c|c|c|}
\hline \multirow[t]{2}{*}{ Isolat } & \multirow[t]{2}{*}{$\operatorname{Pr}$} & \multicolumn{6}{|c|}{$\begin{array}{c}\text { Stress on } \\
\text { Salinity } \\
(\%) \\
\end{array}$} & \multirow[t]{2}{*}{ Mo } & \multirow[t]{2}{*}{ K } & \multicolumn{5}{|c|}{ Sugar fermentation } & \multicolumn{3}{|c|}{$\begin{array}{c}\mathrm{Pa} \\
\text { Hemolysis }\end{array}$} \\
\hline & & 4 & 7 & 10 & 0 & 3 & 6 & & & Ms & G & $\mathrm{S}$ & $\mathrm{L}$ & $\mathrm{Mt}$ & $\alpha$ & $\beta$ & $\gamma$ \\
\hline KPP212 & + & + & + & + & + & + & + & - & - & + & + & + & + & + & - & - & + \\
\hline IP121 & + & + & + & + & + & + & + & - & - & + & + & + & + & + & - & - & + \\
\hline UJ131 & + & + & + & + & + & + & + & - & - & + & + & + & + & + & - & - & + \\
\hline UJ132 & + & + & + & + & + & + & + & - & + & + & + & + & + & + & - & - & + \\
\hline SB141 & + & + & + & + & + & + & + & - & - & + & + & + & + & + & - & - & + \\
\hline
\end{tabular}

\begin{tabular}{|c|c|c|c|c|c|}
\hline \multicolumn{6}{|c|}{ Remarks : } \\
\hline- & $=$ & no reaction/no growth & $\alpha$ & $=$ & partial hemolysis \\
\hline+ & $=$ & reaction/ growth & $\beta$ & $=$ & total hemolysis \\
\hline G & $=$ & Glucose & $\gamma$ & $=$ & no hemolysis \\
\hline K & $=$ & Catalase & $\mathrm{L}$ & $=$ & Lactose \\
\hline Mo & $=$ & Motility & Ms & $=$ & Mannose \\
\hline Mt & $=$ & Mannitol & $\mathrm{Pa}$ & $=$ & Pathogenic test \\
\hline $\operatorname{Pr}$ & & Protease & S & $=$ & Sukrose \\
\hline
\end{tabular}




\section{CONCLUSION}

This study found about 128 isolated Bacillus sp. from intestinal mangrove biota in Lampung Mangrove Center, such as shrimp, mollusc, fish, and crabs from which 94 isolated Bacillus sp. had proteolytic characters, and 5 of them have very good potentials as a probiotic candidate. The five probiotics were: Bacillus sp. KPP212 collected from climbing crab, Bacillus sp. IP121 collected from fish, Bacillus sp. SB141 collected from the mollusc, Bacillus sp. UJ131 and Bacillus sp. UJ132 collected from shrimp. Diversity of Bacillus sp. and biota are found in various types. Therefore, the mangrove of Margasari of Lampung is very important to conserve.

\section{ACKNOWLEDGEMENT}

This study was fully supported and funded by the Coastal and Marine Research Center of the University of Lampung.

\section{REFERENCES}

Anggriani, R., Iskandar, \& Ankiq, T. (2012). Efektivitas penambahan Bacillus Sp. hasil isolasi dari saluran pencernaan ikan patin pada pakan komersial terhadap kelangsungan hidup dan pertumbuhan benih ikan nila merah (Oreochromis niloticus). Jurnal Perikanan dan Kelautan, 3(3), 75-83.

Aryal S. (2015). Haemolysis of streptococci and its types with examples. Retrieved from https://microbiologyinfo.com/haemolysisof-streptococci-and-its-types-with-examples, on April 2018.

Castro R. A., Dourado M. N., de Almeida J. R., Lacava P.T., Nave A., de Melo I. S., de Azevedo J. L., \& Quecine, M. C. (2018). Mangrove endophyte promotes reforestation tree (Acacia polyphylla) growth. Bra₹ Journal Microbiol 49(1), 59-66 doi://10.1016/j.bjm.2017.04.002.

Castro R. A., Quecine M. C., Lacava P. T., Batista B. D., Luvizotto D. M., Marcon J. Ferreira A., Melo I. S., \& Azevedo J. L. (2014). Isolation and enzyme bioprospection of endophytic bacteria associated with plants of Brazilian mangrove ecosystem. Springer Plus, 3, 382 Retrieved from http://www.springerplus. com/content $/ 3 / 1 / 382$, on the $1^{\text {st }}$ December 2020

Damayanti, S. S., Oom, K., \& Effendi, E. M. (2018). Identifikasi bakteri dari pupuk organik cair isi rumen sapi. Ekologia: Jurnal Ilmiah Ilmu Dasar dan Lingkungan Hidup. 18(2), 63-71.

Deivanai S., Bindusara A. S., Prabhakaran G., \& Bhore S. J. (2014). Culturable bacterial endophytes isolated from mangrove tree (Rhizophora apiculata Blume) enhance seedling growth in Rice. Journal of Natural Science, Biology and Medicine. 5(2): 437-444. doi:// 10.4103/0976-9668.136233.

Febrianti, D. (2011). Efektivitas probiotik asal usus udang dalam menghambat pertumbuban vibrio barveyi pada larva udang vaname (Litopenaeus vanname). (Skripsi). Institut Pertanian Bogor.

Hamtini. (2014). Isolasi dan Karakterisasi Bacillus sp. dari ikan lele (Clarias sp.) serta potensinya sebagai probiotik. (Tesis). Institut Pertanian Bogor.

Hamzah T. N. T., Lee S. Y, Hidayat A., Terhem R., Hanum I. F., \& Mohamed R. (2018). Diversity and characterisation of endophytic fungi isolated from the tropical mangrove species, Rhizophora mucronata, and identification of potential antagonists against the soil-borne fungus, Fusarium solani. Frontiers in Microbiology. 9(Article 1707).

Handayani, H. (2011). Optimalisasi substitusi tepung azolla terfermentasi pada pakan ikan untuk meningkatkan produktivitas ikan nila gift. Jurnal Teknik Industri. 12(2), 177-181 doi:://10.22219/JTIUMM.Vol12.No2.177181.

Hapsari, T., Tjahjaningsih W., Alamsjah M. A., \& Pramono H. (2016). Aktivitas enzimatis bakteri proteolitik asal gastrointestinal udang vannamei (Litopenaeus vannamer). Journal of Marine and Coastal Science. 5 (3), 109-118.

Hutabarat, S. (2000). Produktivitasperairan dan plakton telaah terhadap ilmu perikanan dan kelautan. Semarang: Badan Penerbit Universitas Diponegoro.

Ilmiah, S. N., Nisa, R. M., \& Budiasih, W. (2018). Characterisation of Protease from Bacillus licheniformis F11.1 as a bio-detergent agent. Makara Journal of Science, 22(3), 105-112.

Kariada, N.. \& Andin, I. (2014). Peranan mangrove sebagai biofilter pencemaran air wilayah tambak bandeng tapak, Semarang. Jurnal Manusia dan Lingkungan, 21(2), 188-194. 
Kementrian Kehutanan. (2014). Pengelolaan butan mangrove dan ekosisem pantai. sintesis hasil litbang 2010-2014. Pusat Penelitian dan Pengembangan Konservasi dan Rehabilitasi. Badan Penelitian dan Pengembangan Kehutanan.

Kepel, B. J., Widdhi, B., \& Fatimawali. (2020). Pengaruh $\mathrm{pH}$ dan suhu terhadap aktivitas pereduksi merkuri bakteri resisten merkuri tinggi Bacillus cereus yang diisolasi dari urin pasien dengan amalgam gigi. e-GiGi. 8 (1), $15-$ 21.

Khusnan, Dwi, K., \& Agus, P. (2018). Deteksi hemaglutinin, hemolisin dan koagulase secara fenotipik dan genotipik pada Staphylococcus aureus isolat asal broiler. Jurnal Sains Veteriner, 36(1), 103-114.

Maulani B. I. G., Rasmi D. A. C., \& Zulkifli L. (2019). Isolation and characterisation of endophytic bacteria from mangrove Rhizophora mucronata Lam. and antibacterial activity test against some pathogenic bacteria. $4^{\text {th }}$ Annual Applied Science and Engineering Conference Journal of Physics: Conference Series doi://10.1088/17426596/1402/3/033038.

Muliani, M., Nurbaya, N., Arifudin, T., \& Muharijadi, A. (2017). Eksplorasi bakteri filosfer dari tanaman mangrove sebagai bakteri probiotik pada budidaya udang windu, Penaeus monodon. Jurnal Penelitian Perikanan Indonesia. 10(2), 4757.

Pratiwi, I., Rahayu, K., \& Wahju, T. (2013). Eksplorasi bakteri kandidat probiotik di lumpur hutan mangrove Wonorejo. Jurnal Ilmiah Perikanan dan Kelautan, 5(2), 187-192.

Rahmawan, Mohamad, E. A., Suminto, \& Herawati V. E. (2014). Penggunaan bakteri kandidat probiotik pada pakan buatan terhadap efisiensi pemanfaatan pakan, pertumbuhan dan kelulushidupan lele dumbo (Clarias gariepinus). Journal of Aquaculture Management and Technology, 3(4), 257-264.

Samosir, M. F., D. Suryanto, and Desrita. (2017). Isolasi dan identifikasi bakteri potensial probiotik pada saluran pencernaan ikan mas (Cyprinus caprio). Jurnal Aquacoastmarine, 5(1), $1-14$.

Sarastiti, S., Suminto, \& Sarjito. (2020). Identifikasi molekuler spesies bakteri kandidat probiotik yang diisolasi dari usus udang vaname (Litopenaeus vannameı) koleksi dari Kabupaten
Subang, Jawa Barat. Jurnal Pasir Laut, 4, 1-9.

Scharler, U. M. (2011). Whole food-web studies: Mangroves. Treatise on Estuarine and Coastal Science. 6, 271-286.

Seprianto, Feliatra, \& Nugroho, T. T. (2017). Isolasi dan identifikasi bakteri probiotik dari usus udang windu (Penaeus monodon) berdasarkan sekuens gen 16S rDNA. Biogenesis, 5(2), 83-92.

Sinatryani, D., Moch, A. A., Sudarno, and Kustiawan, T. P. (2014). Kelimpahan bakteri selulolitik di muara sungai Gunung Anyar Surabaya dan Bancaran Bangkalan. Jurnal Ilmiah Perikanan dan Kelautan, 6 (2), 143-148.

Subagiyo, Sebastian, M., Triyanto, \& Wilis, A. S. (2015). Pengaruh $\mathrm{pH}$, suhu dan salinitas terhadap pertumbuhan dan produksi asam organik bakteri asam laktat yang diisolasi dari intestinum udang penaeid. Ilmu Kelautan. 20 (4), 187-194.

Subagiyo, Muhammad, S. R. D., \& Wilis, A. S. (2017). Potensi ekosistem mangrove sebagai sumber bakteri untuk produksi protease, amilase, dan selulase. Jurnal Kelautan Tropis, 20 (2), 106-111.

Suhendar, D., Esti, S., \& Asep, S. (2019). Lumpur hitam tanah rawa hutan mangrove Karangsong (Kabupaten Indramayu): Komposisi kimia dan transformasi fasa yang dihasilkan melalui penanganan secara termal. Jurnal Riset Geologi dan Pertambangan, 29(2), 127-139.

Sumardi, Farisi S., Ekowati C. N., Arifiyanto A, \& Rahmawati, D. E. (2020). Halotolerant Bacillus sp. for mannan degradation isolated from mangrove ecosystem at Hanura Beach Lampung. Journal of Pure and Applied Microbilogy (JPAM), 14(2), 1237-1244.

Sumardi, Farisi S., Ekowati C. N., \& Hairisah S. F. (2019). Karakterisasi Enzim Xilanase dari isolat Bacillus sp. UJ131 di hutan mangrove Margasari Lampung Timur sebagai kandidat probiotik. Oseanologi dan Limnologi di Indonesia, 4(3), 167-174. doi://10.14203/oldi.2019. v4i3.201.

Sumardi, Agustrina R, Ekowati C. N., \& Pasaribu Y. S. (2018). Characterisation of protease from Bacillus sp. on medium containing $\mathrm{FeCl}_{3}$ exposed to magnetic field $0.2 \mathrm{mt}$. IOP Conference Series: Earth and Environmental Science, 130. 012046 doi://10.1088/17551315/130/1/012046.

Supriyadi, T. H., and Koesharyani, I. (2008). Survey of viral diseases of pacific white shrimp, 
Litopenaeus vannamei in indonesia. Indonesian Aquaculture Journal, 3(1), 59-68.

Tensiska. (2008). Probiotik dan prebiotik sebagai pangan fungsional. Universitas Pajajaran, Bandung.

Triyanto, A., Isnansetyo, I. D., Prijambada, Widada J., \& Tarmiawati A. (2009). Isolasi, karakterisasi dan uji infeksi bakteri proteolitik dari lumpur kawasan hutan bakau. Jurnal Perikanan, 11(1), 13-18.

Utomo P. B., Sudarno \& Rahardja B. S.. (2019). Identification of proteolytic bacterial isolates in sediment ecosystem of Gunung Anyar Mangrove forest, Surabaya. The $1^{\text {st }}$ International Conference on Fisheries and Marine Science. IOP Conference Series: Earth and Environmental Science. IOP Publishing doi://10.1088/1755-1315/236/1/012060.
Widiastuti, E. L., Arifianti,. R., Khairani, I.A., Christianto, Y., Ara, N. F., \& Maharani, H.W. (2019). Antioxidant effect of Clerodendrum sp. and Acanthus illicifolius methanol extraction on blood profile of male mice induced by $\operatorname{Benzo}(\alpha)$ pyrene. IOP Conference Series: Earth and Environmental Science, 305 https://iopscience.iop.org/ article/10.1088/1755-1315/305/1/012011.

Yulvizar, C. (2013). Isolasi dan identifikasi bakteri probiotik pada Rastrelliger sp. Biospecies, 6(2), 1-7. Retrieved from https://online-journal. unja.ac.id/index.php/biospecies/article/ view/884, on May $18^{\text {th }} 2020$. 